УДК 636.32/.38.09:595.132.7 DOI 10.31210/visnyk2018.03.21

(C) 2018

\author{
Мельничук В. В., кандидат ветеринарних наук, \\ Сорокова С. С., магістр з ветеринарної медицини
}

Полтавська державна аграрна академія

\title{
ОСОБЛИВОСТІ МОРФО-МЕТРИЧНОЇ БУДОВИ STRONGYLOIDES PAPILLOSUS (WEDL, 1856), ВИДІЛЕНИХ ВІД ОВЕЦЬ
}

\section{Рецензент - доктор ветеринарних наук А. А. Замазій}

Наведено результати досліджень щзодо видової ідентифікаиії нематод виду Strongyloides papillosus (Wedl, 1856), виділених від овецьь з урахуванням їх морфометричних характеристик. Встановлено диферениійні морфологічні особливості будови паразитичних форм гельмінтів даного виду - партеногенечних самок, виділених з тонкої кишки тварин. Визначено метричні особливості за 24 показниками у будові тіла збудника стронгілоїдозу овець Strongyloides papillosus, щзо підвищать ефективність його видової ідентифікації. Проведено порівняльний аналіз отриманих морфометричних показників стронгілоїдесів із загальновідомим визначником.

Ключові слова: вівиі, Strongyloides papillosus, нематоди, морфологічні та метричні показники.

Постановка проблеми. Вівчарство - галузь тваринництва, що забезпечує легку промисловість сировиною (вовна, смушки, овчини, шкіра) та споживачів продуктами харчування (м'ясо, жир, молоко і вироби з нього - бринза, сир), які мають цілющі властивості. Продукти з овечого молока підтримують регенерацію клітин, позитивно впливають на хвору печінку, шлунковокишковий тракт, очищають і зміцнюють судини, що значно знижує можливість виникнення інфаркту. Вироби з вовни та овчини за своїми гігієнічними властивостями не мають аналогів, сприяють збереженню здоров'я і продовженню життя людини $[4,5,6]$.

У сучасних умовах господарювання галузь вівчарства може бути однією із перспективних для відновлення та іiі розвитку з позиції підвищення ефективного використання землі, рівня зайнятості населення, забезпечення національного сектору переробної та легкої промисловості сировиною з цілющими властивостями $[1,3]$.

Однією $з$ причин, яка знижує ефективність розвитку вівчарства, є гельмінтозні захворювання, у тому числі стронгілоїдоз. Внаслідок цієї інвазії, молодняк відстає у рості й розвитку, змінюються якісні властивості вовни, іноді відбувається загибель тварин $[2,14]$. Тому визначення особливостей ідентифікації даного збудника $\epsilon$ актуальним напрямом наукових досліджень.
Аналіз останніх досліджень і публікацій, у яких започатковано розв'язання проблеми. Особлива зацікавленість вчених до нематод роду Strongyloides (Grassi, 1879) пояснюється їх циклом розвитку, який характеризується чергуванням паразитичних і вільноіснуючих генерацій. Причому паразитична стадія представлена лише однією партеногенетичною самкою, яка мешкає у верхніх відділах тонкої кишки тварин.

Вільноіснуюче покоління нематод представлено непаразитичними формами - самцями і самками, які живуть у зовнішньому середовищі. Є відомості, що залежно від певних умов, пов'язаних із температурою і вологістю повітря, яйця стронгілоідесів, виділені з фекалій хворих тварин або відкладені у зовнішньому середовищі паразитичною самкою, можуть розвиватися різними шляхами. В одному випадку за прямого розвитку нематод роду Strongyloides 3 яєць виходять рабдитоподібні личинки, які перетворюються на філярієподібні личинки. Вони, досягнувши своєї личинкової зрілості (інвазійні личинки), можуть викликати нове зараження тварин. За непрямого розвитку рабдитоподібні личинки у зовнішньому середовищі перетворюються на роздільностатеве покоління самців і самок. Постембріональні стадії розвитку стронгілоїдесів мають характерні морфологічні відмінності, на чому і заснована їх ідентифікація $[9,11,12,13]$.

Такі специфічні біологічні особливості нематод роду Strongyloides свідчать про становлення паразитизму у непаразитичних організмів, який супроводжується появою відповідних пристосувань. Так, у паразитичної особини - партеногенетичної самки - відбулися регресивні морфобіологічні зміни, внаслідок чого відродження яєць відбувається шляхом партеногеніi. У той же час, личинки стронгілоїдесів у зовнішньому середовищі мають можливість варіабельності біологічного перетворення, що також супроводжується їх морфологічними і біологічними змінами внаслідок пристосування або адаптації до умов існування $[7,8,10]$.

Також потрібно враховувати, що у процесі 


\section{ВЕТЕРИНАРНА МЕДИЦИНА}

формування гельмінтофауністічного комплексу в певних екологічних умовах важливе значення має ряд факторів. Найбільш значущими є морфологічні особливості видів, які у стронгілоїдесів, що паразитують у овець, недостатньо вивчені. У зв'язку з цим вивчення морфо-метричних особливостей паразитичних форм Strongyloides papillosus дозволить доповнити вже існуючі дані і більш повно зрозуміти особливості паразитичного пристосування у даного паразита.

У зв'язку з цим, метою роботи було вивчити особливості видової ідентифікації партеногенетичних самок Strongyloides papillosus, виділених від овець.

У завдання досліджень входило дослідити морфологічні особливості будови стронгілоїдесів виду S. papillosus; встановити метричні видові ознаки нематод виду S. papillosus.

Матеріали і методи досліджень. Дослідження проводилися упродовж 2016-2018 рр. на базі лабораторії кафедри паразитології та ветеринарно-санітарної експертизи Полтавської державної аграрної академії.

Збір нематод проводили методом повного гельмінтологічного розтину органів травного тракту загиблих або забитих овець, які надходили з господарств Полтавської, Київської та Запорізької областей. Вид нематод встановлювали за допомогою визначника за В. М. Івашкіним та ін. (1998).

Біометрію нематод проводили із застосуванням об'єкт-мікрометра, окуляр-мікрометра і мікроскопа при збільшенні $\times 100, \times 400$. Мікрофотографування проводили за допомогою цифрової камери до мікроскопу «MICROmed 5Mpix» (China). Статистичний аналіз отриманих даних проводили 3 використанням пакета прикладних програм Microsoft «EXCEL». Розраховували стандартні відхилення (SD) і середні значення (M).

Результати досліджень. За результатами пара-

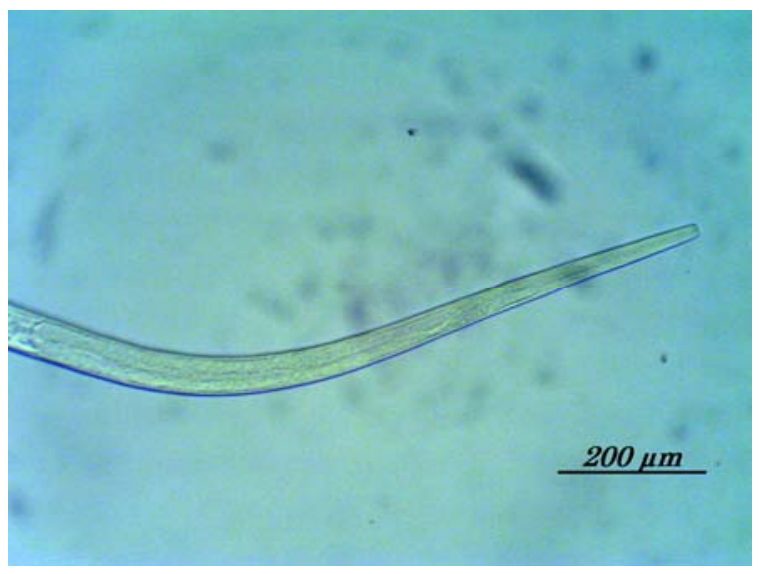

зитологічних досліджень тонких кишок від забитих овець виділений та ідентифікований збудник стронгілоїдозу виду Strongyloides papillosus (Wedl, 1856), який представлений партеногенетичною паразитичною самкою, що має специфічні морфологічні та метричні ознаки. Так, нематоди дрібні, тонкі, напівпрозорі, кутикула ніжна, незначно покреслена в поперечному напрямку. Довжина їх тіла в середньому становить 7,01 $\pm 0,40$ мм (табл.). Ротовий отвір оточений двома губами. Поблизу ротового отвору розташовані дрібні сосочки (рис. 1).

Стравохід добре помітний, його довжина становить 1,04 $\pm 0,08$ мм, ширина - в різних ділянках

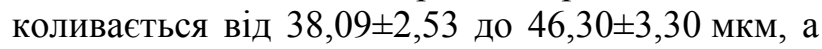
відсоткове співвідношення довжини стравоходу

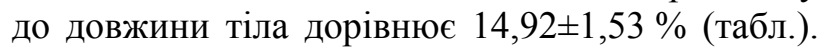
Особливістю гельмінтів даного виду є те, що при переході у кишечник стравохід різко звужується, утворюючи перехват (рис. 2). Ширина цього перехвату становить $21,83 \pm 1,57$ мкм (табл.)

Ще однією особливістю партеногенетичних самок даного виду є морфологічна будова хвостового кінця. Він поступово звужується і закінчується термінальним кінчиком (рис. 3). Ширина хвостового кінця в середній частині була на рівні $14,30 \pm 0,29$ мкм, ширина вершини хвостового кінця становила 7,56 $\pm 0,70$ мкм, а його довжина $60,01 \pm 2,44$ мкм (табл.).

Вульва у самок знаходиться в задній частині тіла, про що свідчать метричні показники. Так, відстань від головного кінця до вульви станови-

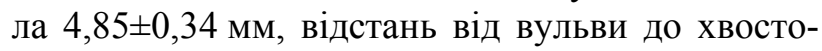
вого кінця - 2,16 $\pm 0,26$ мм, відстань від вульви до

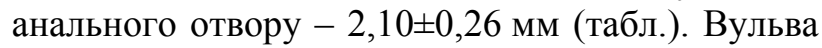
містить дві губи, яєчника два, матка амфідельфного типу, заповнена яйцями характерної для стронгілоїдесів будови (рис. 4).

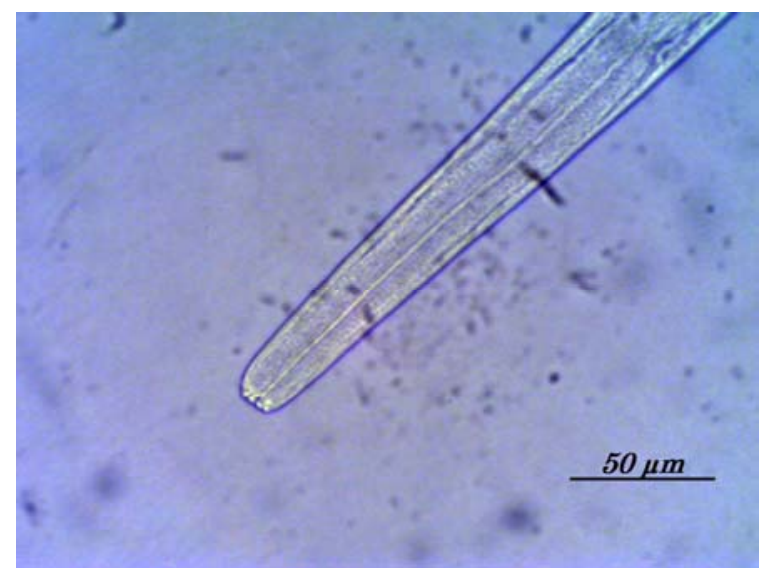

Рис. 1. Головний кінець паразитичної самки Strongyloides papillosus 


\section{ВЕТЕРИНАРНА МЕДИЦИНА}

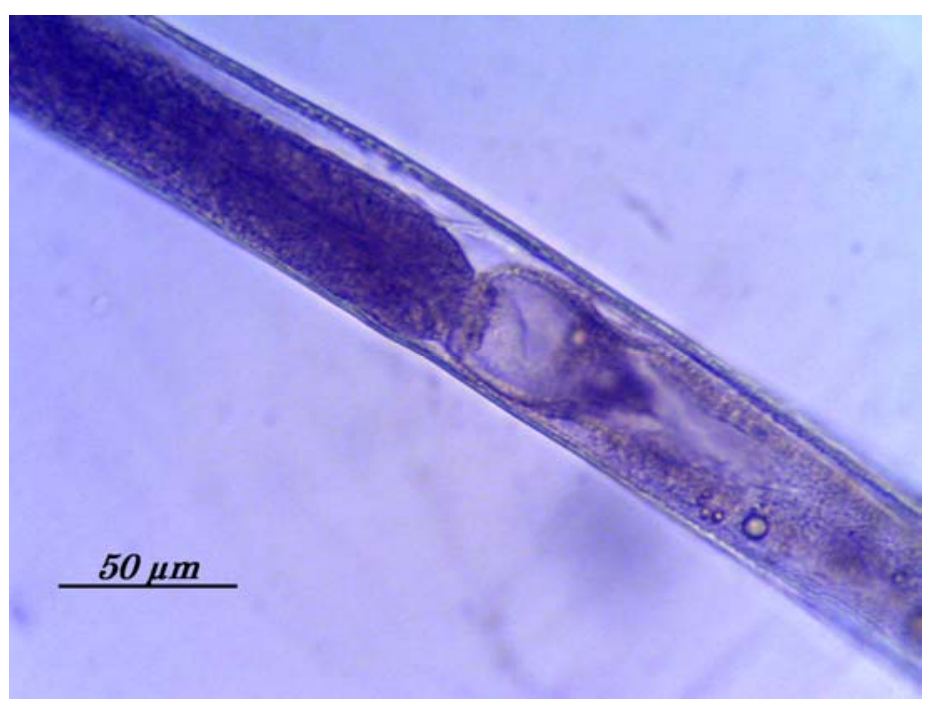

Рис. 2. Ділянка переходу стравоходу в кищечник у паразитичної самки Strongyloides papillosus

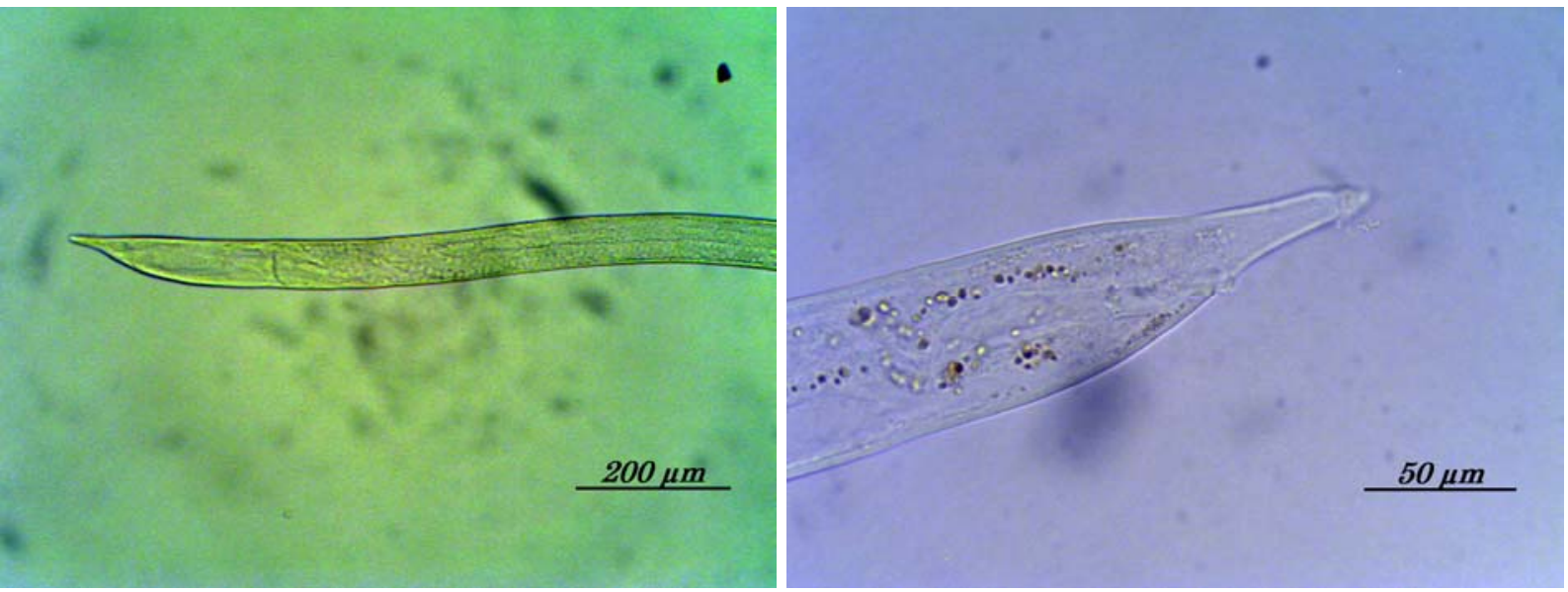

Рис. 3. Хвостовий кінець паразитичної самки Strongyloides papillosus

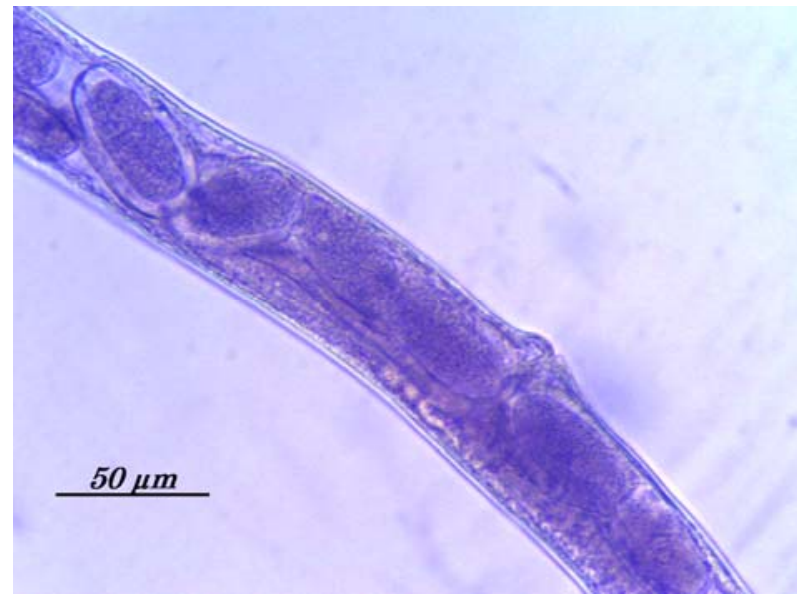

a

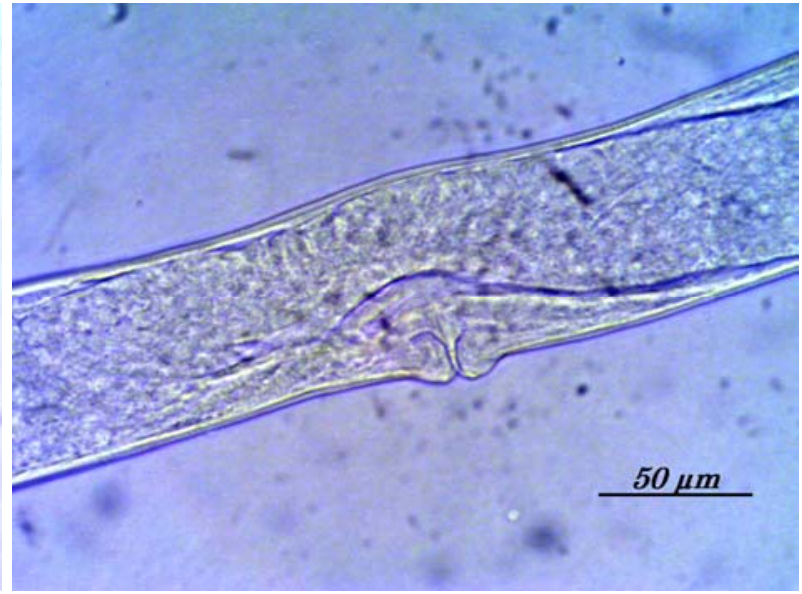

b

Pис. 3. Паразитична самка Strongyloides papillosus:

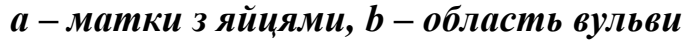


ВЕТЕРИНАРНА МЕДИЦИНА

\section{Метричні видові показники партогенетичних паразитичних самок Strongyloides papillosus, виділених від овець}

\begin{tabular}{|c|c|c|c|c|}
\hline \multirow{2}{*}{ Показники } & \multicolumn{2}{|c|}{$\begin{array}{c}\text { За власними дослідженнями } \\
(\mathrm{n}=20)\end{array}$} & \multicolumn{2}{|c|}{$\begin{array}{c}\text { За визначником В. М. Іваш- } \\
\text { кіна та ін. (1989), мм }\end{array}$} \\
\hline & $\min -\max$ & $\mathrm{M} \pm \mathrm{SD}$ & $\min$ & $\max$ \\
\hline Довжина тіла, мм & $6,08-7,52$ & $7,01 \pm 0,40$ & 4,8 & 6,3 \\
\hline $\begin{array}{l}\text { Ширина тіла в ділянці: } \\
\text { - ротового отвору, мкм }\end{array}$ & $8,11-9,94$ & $8,86 \pm 0,45$ & - & - \\
\hline - середньої частини стравоходу, мкм & $34,08-42,60$ & $39,22 \pm 2,06$ & - & - \\
\hline - дистальної частини стравоходу, мкм & $46,08-54,19$ & $51,05 \pm 2,12$ & - & - \\
\hline - середньої частини тіла, мкм & $48,15-60,36$ & $54,08 \pm 3,96$ & - & - \\
\hline - вульви, мкм & $58,62-68,12$ & $62,41 \pm 2,60$ & - & - \\
\hline $\begin{array}{l}\text { - найширшої його частини (між } \\
\text { вульвою та анусом), мкм }\end{array}$ & $65,98-76,25$ & $71,16 \pm 2,51$ & 0,04 & 0,07 \\
\hline - анального отвору, мкм & $22,69-28,67$ & $26,08 \pm 1,75$ & - & - \\
\hline $\begin{array}{l}\text { Ширина хвостового кінця в серед- } \\
\text { ній частині, мкм }\end{array}$ & $13,87-15,02$ & $14,30 \pm 0,29$ & - & - \\
\hline $\begin{array}{l}\text { Ширина вершини хвостового кінця, } \\
\text { мкм }\end{array}$ & $6,25-8,93$ & $7,56 \pm 0,70$ & 0,006 & 0,009 \\
\hline Довжина стравоходу, мм & $0,95-1,18$ & $1,04 \pm 0,08$ & 0,765 & 1,02 \\
\hline $\begin{array}{l}\text { Довжина стравоходу відносно дов- } \\
\text { жини тіла, \% } \\
\end{array}$ & $12,90-18,37$ & $14,92 \pm 1,53$ & - & - \\
\hline $\begin{array}{l}\text { Ширина стравоходу в середній час- } \\
\text { тині, мкм }\end{array}$ & $30,52-42,15$ & $38,09 \pm 2,53$ & - & - \\
\hline $\begin{array}{l}\text { Ширина стравоходу в дистальній } \\
\text { частині, мкм }\end{array}$ & $40,19-50,21$ & $46,30 \pm 3,30$ & 0,02 & 0,05 \\
\hline $\begin{array}{l}\text { Ширина перехвату в ділянці пере- } \\
\text { ходу стравоходу в кишечник, мкм }\end{array}$ & $19,94-25,71$ & $21,83 \pm 1,57$ & - & - \\
\hline $\begin{array}{l}\text { Відстань від головного кінця до } \\
\text { вульви, мм }\end{array}$ & $4,00-5,22$ & $4,85 \pm 0,34$ & - & - \\
\hline $\begin{array}{l}\text { Відстань від вульви до хвостового } \\
\text { кінця, мм }\end{array}$ & $1,71-2,62$ & $2,16 \pm 0,26$ & 1,8 & 2,3 \\
\hline $\begin{array}{l}\text { Співвідношення заднього кінця тіла } \\
\text { до переднього }\end{array}$ & $\begin{array}{l}1: 1,77- \\
1: 3,02\end{array}$ & $1: 2,27$ & - & - \\
\hline $\begin{array}{l}\text { Відстань від вульви до анального } \\
\text { отвору, мм }\end{array}$ & $1,66-2,56$ & $2,10 \pm 0,26$ & - & - \\
\hline Висота передньої губи вульви, мкм & $5,25-7,61$ & $6,35 \pm 0,61$ & - & - \\
\hline Висота задньої губи вульви, мкм & $3,06-6,87$ & $4,75 \pm 0,84$ & - & - \\
\hline Довжина хвостового кінця, мкм & $54,08-63,45$ & $60,01 \pm 2,44$ & 0,05 & 0,075 \\
\hline Довжина яєць, мкм & $50,12-63,22$ & $58,76 \pm 3,76$ & 0,45 & 0,06 \\
\hline Ширина яєць, мкм & $22,01-36,18$ & $31,18 \pm 3,14$ & 0,025 & 0,04 \\
\hline
\end{tabular}

Примітка: «-»-дані щодо метричних показників відсутні 


\section{ВЕТЕРИНАРНА МЕДИЦИНА}

За результатами проведених досліджень, висота передньої губи вульви дорівнювала $6,35 \pm 0,61$ мкм, а задня губа за розмірами була дещо меншою (4,75 $\pm 0,84$ мкм). Довжина та ширина яєць, в середньому, становили відповідно $58,76 \pm 3,76$ та $31,18 \pm 3,14$ мкм.

За результатами метричних досліджень нами запропоновані 24 показники, що підвищать ефективність видової ідентифікації S.papillosus (табл.).

Окрім стандартних вимірювань запропоновано визначення ширину тіла в різних ділянках тіла, а саме: в ділянці ротового отвору (8,86 $\pm 0,45$ мкм), середньої частини стравоходу $(39,22 \pm 2,06$ мкм), дистальної частини стравоходу $(51,05 \pm 2,12$ мкм), середньої частини тіла (54,08 $\pm 3,96$ мкм), вульви $(62,41 \pm 2,60$ мкм), найширшої частини тіла (71,16 2,5 мкм), анального отвору (26,08 $\pm 1,75$ мкм). Також запропоновано визначення показника співвідношення заднього кінця тіла до переднього, який у паразитичних самок $S$. papillosus дорівнював $1: 2,27$.

У процесі порівняння отриманих нами метричних показників нематод даного виду із визначником за В. М. Івашкіним та ін. (1998) окремі дані відрізнялися, що вказує на мінливість паразитів, внаслідок їх адаптації.

\section{БІБЛІОГРАФІЯ}

1. Беженар I. M. Сучасний стан організації виробництва продукції вівчарства у світі // Аспекти прогнозування економічного та соціального розвитку країн // Збірник наукових праць 3 актуальних проблем економічних наук. - 2013. Ч. 1. - С. 13-24.

2. Богач М. В., Бездєтко Л. С., Кравецьь С. М. Поширення стронгілоїдозної інвазії серед овець різного віку // Аграрний вісник Причорномор'я. - 2010. - Вип. 54. - С. 15-19.

3. Вдовиченко Ю. В. Світові тенденції та стан вівчарства на сучасному етапі трансформування економічних відносин в Україні / Ю.В.Вдовиченко // Вівчарство : міжвідомчий тематичний науковий збірник. - 2014. - Вип. 37. -С. 2-11.

4. Вівчарство України / В. М. Іовенко, П. І. Польська, О. Г. Антонець [та ін.] ; за ред. В. П. Бурката. - К. : Аграрна наука, 2006. - 614 с.

5. Лукіна Г. I. Стан та проблеми розвитку вівчарства в Україні // Економіка АПК. - 2005. №3. - С. 37-41.

6. Смола I. I. Підвищення ефективності вівчарства на підприємствах Херсонської області // Продуктивність агропромислового виробництва. - 2011. - №20. - С. 112-119.
Одночасно нами отримано нові дані за 24 метричними показниками паразитів, а у визначнику (Івашкін В. М. та ін., 1998) наведено лише 9 показників.

Отже, визначення морфологічних ознак з урахування метричних показників партеногенетичних самок виду Strongyloides papillosus дозволить ефективно проводити диференційну діагностику нематод.

\section{Висновки:}

1. Встановлено, що в овець на території центрального та південно-східного регіонів України паразитує збудник стронгілоїдозу виду Strongyloides papillosus.

2. Диференційними морфологічними ознаками паразитичних самок $S$. papillosus є будова головного та хвостового кінців, області вульви, матки, наявність перехвату в області переходу стравоходу у кишечник.

3. Для підвищення ефективності видової ідентифікації партеногенетичних самок S. papillosus запропоновано 24 метричних показника.

Перспективами подальших досліджень є визначення біологічних властивостей Strongyloides papillosus у сезонному аспекті.

7. A molecular evolutionary framework for the phylum Nematoda / M. L. Blaxter, P. De Ley, J. R. Garey [et al.] // Nature. - 1998. Vol. 392 (6671). -P. 71-75.

8. A microarray analysis of gene expression in the free-living stages of the parasitic nematode Strongyloides ratti / F. J. Thompson, G. L. Barker, L. Hughes [et al.] // BMC Genomics. - 2006. Vol. 7. - P. 157.

9. Dewes H. F., Townsend K. G. Further observations on Strongyloides westeri dermatitis: recovery of larvae from soil and bedding, and survival in treated sites // New Zealand Veterinary Journal. - 1990. Vol. 38. - P. 34-37.

10. Eberhardt A. G., Mayer W. E., Streit A. The free-living generation of the nematode Strongyloides papillosus undergoes sexual reproduction // Journal of Parasitology. - 2007. Vol. 37 (8-9). P. 989-1000.

11. Lyons E. T., Tolliver S. C. Review of some features of the biology of Strongyloides westeri with emphasis on the life cycle // Helminthologia. 2015. - Vol. 52 (1). -P. 3-5.

12. Morphological and molecular characterization of Strongyloides ophidiae (Nematoda, Strongylo- 


\section{ВЕТЕРИНАРНА МЕДИЦИНА}

ididae) / K. R. Santos, B. C. Carlos, K. S. Paduan [et al.] // Journal of Helminthology. - 2010. - Vol. 84 (2). - P. 36-142.

13. Parastrongyloides trichosuri, a nematode parasite of mammals that is uniquely suited to genetic analysis / W. N. Grant, S. Stasiuk,
J. Newton-Howes [et al.] // International Journal for Parasitology. - 2006. - Vol. 36. - P. 453-466.

14. Ziomko I. Experimental invasion of Strongyloides papilosus in sheep // Bulletin of the Veterinary Institute in Pulawy. - 2000. - Vol. 44. P. 179-186.

\section{ANNOTATION}

Mel'nychuk V. V., Sorokova S. S. Features of the morphometric structure of Strongyloides papillosus (Wedl, 1856) isolated from sheep.

In modern conditions of farming, the sheep industry can be one of the perspective for recovery and its development from the point of view of increasing the effective using of land, the level of employment of the population, providing the national sector of processing and light industry with raw materials with medicinal properties. One of the reasons that reduces the efficiency of sheep breeding is helminthic diseases, including stronhyloidosis. As a result of this invasion, the young species lose in growth and weight, changes quality of wool, sometimes the death of animals occurs. Therefore, the determination of the features of the identification of this causative agent is an actual direction of scientific research.

The purpose of the work was to study the features of the species identification of parthenogenetic females Strongyloides papillosus isolated from sheep. The task of the research was to explore the morphological features of the structure of the stronhyloid species of the $S$. papillosus species; to establish metric species characteristics of nematodes of S. papillosus species.

The research was conducted during 2016-2018 in the laboratory of the Department of Parasitology and Veterinary and Sanitary Expertise at Poltava State Agrarian Academy. The collection of nematodes was carried out by the method of complete helminthic autopsy of organs of the digestive tract of dead or slaughtered sheep that came to hand from farms of Poltava, Kyiv and Zaporizhzhia regions.

As a result of parasitological research of small intestines from slaughtered sheep, a stronhyloidosis agent of the species Strongyloides papillosus (Wedl, 1856) was identified, which is represented by a parthenogenetic parasitic female with specific morphological and metric characteristics.

Differential morphological features of parasitic females $S$. papillosus are the structure of the anterior and tail end, vulva area, uterus, and the presence of interception in the area of the esophagus transition into the intestine. To increase the effectiveness of species identification of parthenogenetic females S. papillosus, 24 metric indicators are offered.

Prospects for further research are the determination of the biological qualities of Strongyloides papillosus in the seasonal aspect.

Key words: sheep, Strongyloides papillosus, nematodes, morphological and metric indicators. 